\title{
The Aptness of Market Orientation Practices on Contractors' Business Performance: A Look at the Northern State of Malaysia
}

\author{
Mohd Hazman Fitri Hussin, Ahmad Shazeer Mohamed Thaheer, Muhammad Izwan Mohd Badrillah, \\ Mior Harris Mior Harun, and Shahrin Nasir
}

\begin{abstract}
The concept of market orientation has received attention because of its conceptual and practical values. In general, market orientation focus on customer orientation, competitor orientation, and inter-functional coordination to achieve organizational success. Thus, it is assumed the practices of market orientation will lead the organization into market-driven and consequently lead to superior organizational performance. Failure to develop market orientation may adversely affect business performance. However, the context in which the concept is been applied need to be considered. This study examines the aptness of market orientation on business performance among project contractors in a northern state of Malaysia. The focus is on the level of market orientation practice by the contractors, relationship between market orientation and business performance, and the difference between contractor's demographic factors toward market orientation. The results show that larger project contractors tend to practice more market orientation compared with smaller project contractors. Nevertheless, there was no difference in market orientation practice between contractors' categories and contractors' (company) age. However, this study found that market orientation has significant negative correlation with work value received. Therefore, this study would be useful for the contractors to evaluate their practices of market orientation.
\end{abstract}

Index Terms-Market orientation, business performance, contractors, projects.

\section{INTRODUCTION}

Nowadays contractors in Malaysia face fierce competitive challenges either in global market setting or in local market setting. Moreover, the uncertainty of the global economic condition can also bring challenges to the growth of the contractors' market, strategy, and performance. Therefore, in such low-growth and high-competition markets, the relationship between market orientation and performance is considerable [1]. More importantly, [2] noted that though substantial growth has occurred in services from an economic view point, the main challenge is managing services branding [2].

Market orientation can help to increase the business performance if implemented appropriately [3]. In order to achieve this, business organizations in Malaysia should be vigilant to the development of new market profile. They must deliver their services based on market driven and value added

Manuscript received September 7, 2013; revised November 15, 2013.

Ahmad Shazeer Mohd Thaheer is with the University Technology MARA (UITM) Malaysia (e-mail: ahmadshazeer@salam.uitm.edu.my). to the customers. As a result, to satisfy customer's needs and to capture the value they created, service firms need to rely on reputation building and branding [4].

In Malaysia, the contractors gain their market from demand in housing, industrial building, infrastructure project, and commerce. In addition, activities of the contractors can be categorized into three categories which are building construction, civil engineering, and mechanical and electrical. These activities have contributed to the development of the different states and consequently construct the economic structures of this country. Nevertheless, there are several concerns among the contractors in conducting their business. According to [5], among the problems that faced by the Bumiputera contractors are marketing problems and threat from competitors. Thus, market orientation could serve as a mechanism to enable the contractors to manage their markets and competitors effectively.

Initially, market orientation appeared to be adopted only in large, multinational and international companies. Most of studies conducted have not considered the differences of company size as well as the specific features of small and medium-sized contractors which could affect market orientation. As asserted by [6], market orientation can has a positive relationship with business performance. According to [7], although market orientation delivers superior performance in the western economies, the implementation of market orientation in other economies still leaves some gaps in both the theory and practice of marketing. In addition, there are also some market and industry context that may not require market orientation to achieve superior business performance. For example, market orientation is ineffective when the cost of practicing market orientation outweigh its benefit [8].

Therefore, this study will fill the gap by situating market orientation in the context of small and medium-sized contractors in Malaysia. Specifically the aptness of practicing the customer orientation, competitor orientation, and inter-functional coordination by the contractors will be examined in order to determine their effects on business performance. The findings of this study would be useful to the contractors in order to evaluate their practices of market orientation and subsequently to remain competitive.

\section{LITERATURE REVIEW}

\section{A. The Importance of Market Orientation}

According to [9], the term market orientation implies 
listening to customers and responding to their interest and needs. On a similar view, [10] defined in terms of an organization's customer orientation, competitor orientation and its inter-functional coordination. Meanwhile, [11] suggest that market orientation increases with customer connectedness which, would also be expected to strengthen with market focus. In general, such evidence suggested that market focus does impact market orientation in a positive manner.

Market orientation provides solid foundation for value creating capabilities [1]. According to [12], growth can be achieved by identifying and entering new markets. Furthermore, [13] stated that customer empowerment links customer activity towards shaping customer-firm interactions. Firms need to place their emphasis on achieving superiority in firm value appropriation such as customer attraction, customer retention, customer satisfaction, and cross-selling that in turn enhances their marketplace performance in financial value appropriation indicators such as market share, sales growth, and profitability [14].

In addition, market orientation is also synonymous with organizational learning because it leads to market-driven [1]. Therefore, it is believe that the practices of market orientation will lead the contractors into learning organization and consequently lead to superior business performance. On the other hand, failure to develop market orientation may adversely affect business performance [15].

Above all, market orientation is not only the responsibility of marketing department, it involve all business functions [1]. [16] stated that organizational learning constantly evolve through learning, discovery, and adaptation. A firm's capacity to gather and interpret knowledge from the market, or "market-sensing capability," is seen to evolve from market orientation. By focusing on market orientation, it will help business organization to create customer value. Therefore, market orientation also facilitates firm's ability to anticipate, react and capitalize of environmental changes, thereby leading to superior performance [17].

\section{B. Dimensions of Market Orientation}

Firstly, customer is very important for every company. The heart of market orientation is its customer focus. According to [15], customer orientation or customer focused business is likely to be more interested in long term business success as opposed to short-term profits.

Therefore, firms possessing a high level of market orientation are more likely to achieve a higher business performance with respect to customer satisfaction [18].

Secondly, is to be competitor oriented. [6] stated that firms should understand and identify the short-term strengths and weaknesses and long-term capabilities and strategies of both current and future competitors. [15] also added that competitor orientation or competitor focused is where firms seek to identify their own strengths and weaknesses to keep pace or stay ahead in the market. It is widely accepted that focusing on the connection and collaboration between the firm and the customer results in will result in greater customer satisfaction [13]. The competitor orientation parallels the customer orientation in information gathering and includes a systematic analysis of the competitors' technological capabilities in order to assess their ability to satisfy the same buyers [19].

The last dimension is inter-functional coordination. It is important for all departments to communicate information gathered from customers and competitors and to coordinate their effort in order to create superior value for customers [20], [21] mentioned that market orientation involves multiple departments sharing information about customers and engaging in customer linking activities designed to meet customer needs". However, according to [22] a factor that gives harmful affects to market-oriented activity is interdepartmental conflict. The authors suggested that it is important for management to control its exacerbation through methods such as cross functional activities and training, a focus on overall objectives, alignment of departmental objectives and a sense of synergy and commitment within the organization.

\section{Market Orientation and Business Performance}

Market orientation is viewed as a source of sustainable competitive advantage for an organization because it helps to create superior value for customer [6]. Therefore, it can be assumed that an increase in market orientation can be expected to result in the higher business performance of an organization. There are many studies that found a positive link between market orientation and business performance [23].

In a study by [6], they used relative return on asset to measure business performance. They found that businesses which have a higher degree of market orientation also have greater profitability. In another study, [20] mentioned that market orientation is positively related to business profitability, measured by return on investment (ROI). They proved that becoming and remaining market oriented is essential for a company's success. [24] suggested that market orientation is related to overall business performance. However, it is only significant when overall performance is assessed by the subjective measure and market share may not be an appropriate indicator of business performance.

In contrast, the study by [25] did not find significance on the relationship between market orientation and quantitative performance. [26] who conducted a study about manufacturing and travel industry in Malaysia argued that the relationship between market orientation and business performance is partially significant that is on marketing competency. [27] proved that the positive effects of market orientation on business performance do not accrue immediately, because a change in the market oriented efforts take place slowly and is costly.

\section{CONCEPTUAL FRAMEWORK AND HYPOTHESIS DEVELOPMENT}

This study focuses on the market orientation and business performance. According to [28] to create continuous superior value for customers, a business must be customer oriented, competitor oriented, and inter-functionally coordinated. They also added that a series of activities dictated by market orientation create superior customer value, which in turn brings superior return to the firms. Based on the previous 
literature, the theoretical framework for this study is presented below.

\begin{tabular}{|l|l|}
\hline Market Orientation & Business Performance \\
- $\begin{array}{l}\text { Customer } \\
\text { Orientation } \\
\text { Competitor } \\
\text { Orientation } \\
\text { Inter-functional } \\
\text { Coordination }\end{array}$ & - $\begin{array}{l}\text { Growage Net Income } \\
\text { Work Value } \\
\end{array}$ \\
& - $\begin{array}{l}\text { Received } \\
\text { Number of Contract } \\
\text { Received } \\
\text { - } \\
\text { Number of Contract } \\
\text { Renewed }\end{array}$ \\
\hline
\end{tabular}

Market orientation improves result of service enterprise in service firms [21]. Other studies found positive relationship between market orientation and performance [23]. In the Malaysian context, the contractor industries is more on business to business (B2B) and it is quite different from the retailing or manufacturing service which generates their income from sales. The contactors gain their business from the tenders offered by government bodies or private companies. Hence, the business performance measurement is quite different from retail business or manufacturing business in terms of objective performance and judgmental performance. A number of US-based studies found that market orientation has a positive relationship with business performance [6] but the implementation of market orientation in other economies still leaves some gaps in both the theory and practice of marketing [7].

Thus, this study hypothesized that:

H1: Market orientation is positively associated with business performance.

H1a : Market orientation is positively with net income growth.

$\mathrm{H} 1 \mathrm{~b}$ : Market orientation is positively related with wok value received.

H1c : Market orientation is positively related with number of contact received.

H1d : Market orientation is positively related with number of contract renewed.

This study will also examine the level market orientation by the different company's demographic factors that are contractor's classes, contractor's categories, and company ages. However, there is no literature specifically associated with market orientation on contractor's class, contactor's categories, and company's age. This study will review the literature which is similar to those demographic factors that is company's size. According [29] to understand the mechanism of market orientation and its development, the size of organizations has to be taken into account. According to a study by [30], they stated that the relationship between market orientation and performance changes with the changes in the size of company. Market orientation is applicable for small, large and producing companies [23], small enterprise and producing enterprises. Thus, this study hypothesized that:

$\mathrm{H} 2$ : The level of market orientation is different between the contractor's classes.

H3: The level of market orientation is different between the contractor's categories.
H4: The level of market orientation is different between the company's ages.

\section{Methodology}

This study uses a cross-sectional study design and employed $t$ survey method based on questionnaire. Self-administered questionnaire was conducted as the means to data collection. Then, the unit of analysis for this study was organizational level.

\section{A. Measurement}

The market orientation measurement was used and it was developed by [6]. It consisted 15 items which described customer orientation (6 items), competitor orientation (4 items), and inter-functional coordination (5 items). The Cronbach's Alpha for this measurement is 0.88 and this exhibits satisfactory level of reliability [6]. The scale composed 15 Likert-type items scored on 7-point scales ranging from strongly disagree (1) to strongly agree (6). Meanwhile, the business performance measure is adapated base on: Return on assets (ROA) [3], yearly work value [5] and customer retention [31]. These dimensions of business performance were modified to suit the contractor's setting.

\section{B. Sampling}

The population of this study is the contractors in Perlis. The sampling frame is obtained from the membership directory of [32]. The membership directory contains the list of 88 contractors in Perlis which is divided into 5 classes according to the project value which is allowed to be worked by them. Those classes are A Class, B Class, BX Class, C Class and D Class. According to [33] the sample size for any population size of 90 is 73 . Therefore, this study will take 73 samples using stratified random sampling.

\section{Data Analysis}

Inferential analysis was employed to find the differences and correlation among variables. It was also be used to explain the variance. To find the differences, one way analysis of variance (ANOVA) was used. The purpose was to examine differences in the level of market orientation performed by different demographic factors that were classes of contactor, categories of contractor, and age of company.

Then, Pearson correlation was also employed to find correlation between variables. Pearson Correlation was used to describe the strength and direction of the relationship between two variables [34]. For the purpose of this study, the elements of market orientation such as customer orientation, competitor orientation, and inter-functional coordination was measured to ensure that all three components are related to market orientation. In addition, the correlation between market orientation and business performance dimensions (net income growth, work value, number of contacts received, and number of contract renewed) was also measured to indicate whether there is any association between the variables.

Then to explain the variance of market orientation on variables, multiple regressions was employed. Multiple regressions was used to examines predictive ability of market 
orientation on net income growth, work value, number of contracts received, and number of contract renewed. According to [31], the sign of beta coefficient $(\beta)$ is observed either the sign is in the same direction as hypothesized or not in the same direction as hypothesized. He added that the significance of beta coefficient is also observed to determine whether the contribution of the variable is significant or not. The regression procedures are subject to a one-tailed test of statistical significance at three different levels: highly significant $(p<0.001)$, significant $(p<0.01)$ and $(p<0.05)$. [10] also stated that, which superior performance inherently dependent on understanding and satisfying customer needs better than one's competitors.

\section{FINDINGS}

Descriptive statistics such as maximum, minimum, means, standard deviations, and variance were obtained for the demographic factors, independent variables and dependent variable. The mean for contractor's class is 3.33 and the mean for contractor's category is 1.79. The average companies' age stated with the mean of 2.94. For the business performance, the mean for average net income growth is 17.39 and the mean for work value received is 1427742 . Then, the mean for number of contract receive and the number of contact renewed gives the mean score of 3.55 and 1.27 respectively. Lastly, on a six-point scale, the mean score of market orientation is 5.13 and the variance is 0.215 which indicated that most respondents were very close to the mean of all the variables.

The relationship between market orientation and the business performance elements was measured using Pearson correlation coefficient. It was found that market orientation has negative relationship with work value received $(r=-0.54$, $p<0.01)$. However, there were no relationships between market orientation and average net income $(r=-0.14, p>$ $0.05)$, market orientation and number of contract received ( $r$ $=-0.20, p>0.05)$, and market orientation with number of contract renewed $(r=0.061, p>0.05)$.

TABLE I: MULTIPLE REGRESSION

\begin{tabular}{|c|c|c|c|}
\hline Factors & $\begin{array}{c}\text { Beta } \\
\text { (standard } \\
\text { coefficient) }\end{array}$ & P value & VIF \\
\hline $\begin{array}{c}\text { Average Net Income } \\
\text { Growth }\end{array}$ & -0.014 & 0.939 & 0.06 \\
\hline $\begin{array}{c}\text { Work Value } \\
\text { Received }\end{array}$ & -0.542 & 0.001 & 12.87 \\
\hline $\begin{array}{c}\text { Number of Contract } \\
\text { Received }\end{array}$ & -0.201 & 0.262 & 1.305 \\
\hline $\begin{array}{c}\text { Number of Contract } \\
\text { Renewed }\end{array}$ & -0.28 & 0.736 & 0.116 \\
\hline$*$ Correlation is significant at $p<0.05$, two-tailed. & \\
\hline
\end{tabular}

For the differences in market orientation practice among the demographic factors, there were no differences between the overall contractors' classes and market orientation practices at $F=1.366$ and $p>0.05$, contractors' categories and their market orientation practice at $F=0.187$ and $p>$ 0.05 , companies' age and the market orientation practice at $F$ $=0.409$ and $p>0.05$. Therefore, hypothesis two, hypothesis three, and hypothesis four were rejected.

For the variance explained (Table I), the adjusted R-square obtained was $(0.271)$ means that $27.1 \%$ of the variance in the dependent variable (work value received) was explained by the variation in the independent variable, market orientation. Market orientation is found to has a negative influence on work value received $(\beta=-0.542, p=0.001)$.

\section{DisCUSSION AND CONCLUSION}

This study demonstrated that the level of market orientation practice among contactors in this study's setting is mixed. In contrast with the studies by [35], and [6], contractors tend to practice market orientation by focusing on the needs of their customer, generating information on competitor and coordinating their internal function. Furthermore, the contactors tend to focus on long term success and profitability. However, the high level of market orientation practice by the contractors could be viewed as a common and routine practice in their business setting. This is due to the low variance in practicing market orientation among the contractors. The majority of contactors in this study practice market orientation. Therefore, this study found that contractors could not be classified according to their market orientation practice since there is no difference in market orientation practice among contractors.

This study also shows that market orientation does not has significant relationship with the measurement of contractor's business performance which are average net income growth, number of contract received, and number of contract renewed. This result would appear to provide somewhat mixed support for the importance of market orientation. Market orientation seems to have no contribution to the business performance of contractors.

In this study, the unproductive application of market orientation was found in the relationship between market orientation and work value received. The relationship was found to have negative relationship. The contactors consist of small and medium size companies. It is interesting to note that measures of customer and competitor orientation that most closely resemble those use for large firm proved least relevant for the emergent firm [36]. Therefore, contractors should thrive on their operation and production efficiency instead of practicing market orientation.

For future research in this field, the larger sample size will provide more confidence in the results. This study only obtained 33 organizations as the samples. Furthermore, the questionnaire shall be distributed though mail to increase the response rate and sample size since the self-administered questionnaire was very time consuming. Then, for the measurement, this study uses the market orientation instrument by [6] and it was used by them to measure market orientation in large multinational companies. Since this study involve contactors in small and medium size companies, the measurement seems not accurately measure market orientation for the small and medium size companies. Therefore, for the future research, it is suggested to use the instrument that is tailored to measure market orientation of the small and medium size companies.

In conclusion, the findings from this study give academicians and managers a much stronger basis in the 
aptness to practice market orientation among the contractors. Market orientation could bring benefit in some industry or business but sometime it also brings negative effect to the industry or business. This study found that market orientation does not contribute in increasing the business performance among contractors. The measurement of contractor's business performance that are average net income growth, number of contract received, and number of project renewed do not have relationship with market orientation. Moreover, market orientation could bring negative effect to the work value received. This implies that market orientation is unproductive and unnecessary for the contractors in this study's context.

\section{REFERENCES}

[1] N. F. Slater and J. C. Narver, "Market orientation, customer value, and superior performance," Business Horizons, vol. 37, pp. 1-8., 1994.

[2] K. Moller, R. Rajala, and M. Westerlund, "Service innovation myopia? A new recipe for client-provider value creation," California Management Review, vol. 50, no. 3, pp. 31-48, 2008.

[3] C. Guo, "Market orientation and business performance: A framework for service organization," European Journal of Marketing, vol. 36, no. $9,2001$.

[4] D. Lepak, K. G. Smith, and M. S. Taylor, "Value creation and value capture: a multilevel perspective," Academy of Management Review, vol. 32, no. 1, pp. 180-94, 2007.

[5] H. Sudin, Y. Ab.Aziz, and O. Abdul Rahim, "Bumiputera di Sektor Pengkontraktoran: Isu dan Cabara," Percetakan Ustaras Sdn. Bhd., Alor Setar,1999.

[6] J. C. Narver and S. F. Slater, "The Effect of Market Orientation on Business Profitability," Journal of Marketing, vol. 54. 1990.

[7] I. Bathgate, M. Omar, S. Nwankwo, and Y. Zhang, "Transition to a market orientation in China: preliminary evidence," Marketing Intelligence \& Planning, vol. 24, no. 4, pp. 332-346, 2006.

[8] A. M. Pelham and D. T. Wilson, "A longitudinal study of the impact of market structure, firm structure, strategy, and market orientation culture on dimensions of small-firm performance," Journal of the Academy of Marketing Sciences, vol. 24, no. 1, pp. 27-43, 1996.

[9] M. Debruyne and M. Schoovaerts, Innovation outside the Lab: Strategic Innovation as the Alternative, Belgium: Flanders District of Creativity, Research Repor, Leuven, 2006.

[10] M. Augusto and F. Coelho, "Market orientation and new-to-the-world products: Exploring the moderating effects of innovativeness, competitive strength and environmental forces," Industrial Marketing Management, vol. 38, pp. 94-108, 2009.

[11] P. C. Verhoef and P. S. H. Leeflang, "Understanding the marketing department's influence within the firm," Journal of Marketing, vol. 73 , pp. 14-37. 2009.

[12] F. W. Kellermanns and K. A. Eddleston, "Corporate venturing in family firms: Does the family matter?" Entrepreneurship Theory and Practice, vol. 30, pp. 837-854, 2006.

[13] G. Ramani and V. Kumar, "Interaction orientation and firm performance," Journal of Marketing, vol. 72, no. 1, pp. 27-45, 2008.

[14] A. O'Cass and L. V. Ngo, "Examining the firm's value creation process: a managerial perspective of the firm's value offering strategy and performance," British Journal of Management, 2010.

[15] R. A. Heins, "Market Orientation: Toward an Integrated Framework," Academy of Marketing Science Review, 2000.

[16] S. Olavarrieta and R. Friedmann, "Market orientation, knowledge-related resources and firm performance," Journal of Business Resources, vol. 61, no. 6, pp. 623-30, 2008.

[17] A. Shoham, G. M. Rose, and F. Kropp, "Market orientation and performance: a meta-analysis," Marketing Intelligence and Planning, vol. 23 , no. $5,2005$.

[18] A. O'Cass and L. V. Ngo, "Achieving customer satisfaction in services firms via branding capability and customer empowerment," Journal of Service Marketing, vol. 25, no. 7, pp. 489-496, 2011.

[19] G. T. M. Hult, D. J. Ketchen, and S. Slater, "Market orientation and performance: an integration of disparate approaches," Journal of Strategic Management, vol. 26, pp. 1173-1181, 2005.

[20] J. C. Narver, S. F. Slater, and D. L. Maclachlan, "Responsive and proactive market orientation and newproduct success," Journal of Product Innovation Management, vol. 21, pp. 334-347, 2004.
[21] A. H. Kirca, S. Jayachandran, and W. O. Bearden, "Market orientation a meta-analytic review and assessment of its antecedents and impact on performance," Journal of Marketing, vol. 69, no. 2, pp. 24-41, 2005.

[22] S. Pulendan, R. Speed, and R. E. Widing, "Market planning, market orientation and business performance," European Journal of Marketing, vol. 37, no. 3/4, pp. 476-497, 2002.

[23] J. C. Casillas, A. M. Moreno, and J. L. Barbero, "A configurational approach of the relationship between entrepreneurial orientation and growth of family firms," Family Business Review, vol. 23, pp. 27-44, 2010.

[24] M. M. S. Sany, Z. Y. Rushaimi, and A. Rozita, "Market Orientation Critical Success Factors of Malaysian Manufacturers and Its Impact on Financial Performance," International Journal of Marketing Studies, vol. 1, no.1, May 2009.

[25] M. L. Perry and A. T. Shao, "Market orientation and incumbent performance in dynamic market," European Journal of Marketing, vol. 36, no. 9/10, pp. 1140-1153, 2002.

[26] N. A. Aziz and N. M. Yassin, "The influence of market orientation on maketing competency and the effect of internet-marketing integration," Asia Pacific Journal of Marketing and Logistics, vol. 16, no. 2, pp. 3, 2005.

[27] F. Langerak, E. J. Hultink, and H. S. J. Robben, "The impact of market orientation, product advantage, and launch proficiency on new product performance and organizational performance," Journal of Product Innovation Management, vol. 21, no. 2, pp. 79-94, 2004.

[28] L. Beck, W. Janssens, M. Debruyne, and T. Lommelen, "A study of the relationships between generation, market orientation, and innovation in family," Family Business Review, vol. 24, no. 3, pp. 252-272, 2011.

[29] J. F. Nielsen, V. Host, J. Jaensson, S. Kock, and F. Selnes, "Market orientation in Nordic banks: does nationality matter?" European Journal of Marketing, vol. 37, no. 11/12, pp. 1818-1841, 2001.

[30] J. Gonzalez and L. Chiagouris, "Internet Support Companies: The Impact of Marketing Orientation," Journal of Internet Banking and Commerce, vol. 11, no. 1, April 2006.

[31] W. Ngansathil, "Market Orientation and Business Performance: Empirical Evidence from Thailand," Unpublished doctoral thesis, The University of Melbourne, Melbourne, 2001.

[32] Malay Malaysia Business Chamber subsidiary of Perlis, 2006.

[33] R. Y. Cavana, B. L. Delahaye, and U. Sekaran, Applied Business Research: Qualitative and Quantitative Method, Australia: John Wiley and Sons, 2000.

[34] M. N. N. Azila, "Customer- Orientation Behavior: Antecedents and relationship with sales performance," Unpublished doctoral thesis, Universiti Utara Malaysia, Sintok, 2005.

[35] B. J. Jaworski and A. K. Kohli, "Market orientation: antecedents and consequences," Journal of Marketing, vol. 57, pp. 53-70, 1993.

[36] A. Fischer and R. Reuber, "Targeting export support to SMEs: owners' international experience as a segmentation basis," Small Business Economics, vol. 20, no. 1, pp. 69-82, 2003.

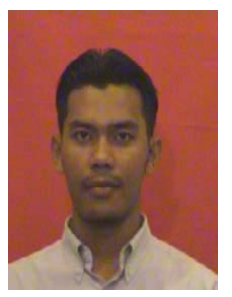

Mohd Hazman Fitri Hussin was born in Perlis, Malaysia and holds BBA (Management) and MSc (Management). He currently lives in Cyberjaya and commutes everyday to Puncak Alam, Selangor. Mohd Hazman joined Faculty of Business Management, Universiti Teknologi MARA (UiTM) in 2011. He teaches Management, Organizational Behaviour, International Management, and Introduction to International Business courses. He has produced several research papers for local and international publications in the field of organizational behaviour, knowledge management, and social network. He is also involved in the invention and innovation competition at international level.

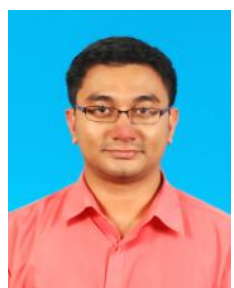

Ahmad Shazeer Mohamed Thaheer was born in Kuala Lumpur on $13^{\text {th }}$ March 1986 . He obtained Master of Business Administration majoring in Corporate Management from Universiti Teknologi MARA, Shah Alam, Selangor, Malaysia in 2010. He had worked at Scope International (M) Sdn Bhd, a subsidiary of Standard Chartered Plc for 2 years before joining Universiti Teknologi MARA in Shah Alam, Malaysia as a lecturer until now. His first journal article titled Employees' Trust And Work Performance: The Influence of Perceived Satisfaction Towards The Performance Appraisal (PA) Process will be published in IEEE Xplore this year. His current research interest are international marketing and international human resource management. 


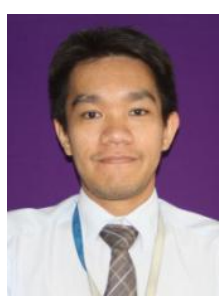

Muhammad Izwan Mohd Badrillah was born in Kuala Lumpur on $13^{\text {th }}$ March 1983. He graduated with a bachelor's degree in Logistics Management from Northumbria University in 2008. In 2009, he obtained his Master of Business Administration (MBA) majoring in Corporate Management from Universiti Teknologi MARA, Shah Alam, Selangor, Malaysia. He joined Universiti Teknologi MARA in Shah Alam, Malaysia as a lecturer in 2009 and is currently teaching various business related subjects. Prior to him joining UITM, he was a Procurement Executive for Petroliam Nasional Berhad (PETRONAS) for 2 years. Muhammad has produced and presented research papers locally and internationally. He is also actively involved in consultation especially in the areas of change management and information technology. His current research interests are sustainable and reverse logistics, information technology and service quality.

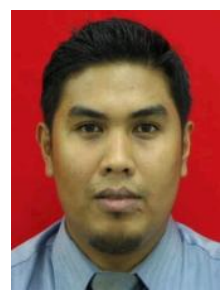

Mior Harris Mior Harun is a senior lecturer a Universiti Teknologi MARA Malaysia. He holds a Bachelors of Science in Marketing and Economics from Pennsylvania State University USA, an MBA in International Business from San Diego State University USA and a PhD in International Business from University of Reading UK. He currently teaches MBA International Business, Undergraduate International Business, International Marketing, International Management and Global Market Places. During his time at UiTM, he is responsible for running the post-graduate international student exchange programmes and international collaborations activities. His research interest include the impact of culture towards international advertising, impact of policies toward international business and various other areas in international marketing and international business. $\mathrm{He}$ publishes his researches in quality international journals and presents his research outputs at a variety of international conferences.
Dr. Mior has various working experiences in the private sector in Malaysia. He worked as a Marketing Executive at MATRADE, a Malaysian export promotion agency under the Ministry of International Trade and Industry. He also worked as a Financial Analyst for Permodalan Nasional Berhad, the largest fund investment company in Malaysia. During his early working career he also worked as a Quality Executive at ASTRO, a leading pay TV provider in Malaysia.

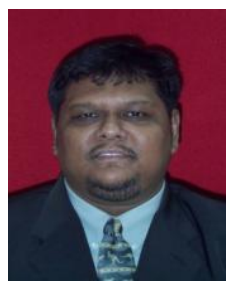

Shahrin Nasir is a senior lecturer at the centre for Transport and Operations Management Studies, Faculty of Business Management, Universiti Teknologi MARA. He holds a MSc In International Transport, Cardiff University. Currently, he is a $\mathrm{PhD}$ candidate at Royal Institute of Technology (KTH), Stockholm Sweden. He is also the Chartered Member of the Chartered Institute of Logistics \& Transport (CMILT). His expertise is in logistics and freight movement. His previous work in the logistics and freight industry are as follows: In 2004-2005, he was part of the co-writer for the logistics chapter for Malaysia's Industrial master Plan 3 (IMP 3) In 2006, he was the technical team leader for Bumiputera Commercial and Industrial Community Cluster, Innovative Blueprint: CWG: Transport and Logistics by Economic Planning Unit, Prime Minister Department Malaysia. In 2007, he led a project commissioned by Economic Planning Unit, Malaysia on Strategies to strengthen Bumiputera Logistics Service Providers. From 2008 until now his research area is related to road/rail intermodal between ports and hinterland in Malaysia. His research is focusing on developing innovative approach in promoting intermodal movement for Malaysian environment. 